\title{
Human constituents: Holistic approach for diagnosis of COVID-19
}

\author{
D. S. Kalana Mendis, Ph.D.
}

Senior Lecturer, Department of Information Technology, Advanced Technological Institute, Dehiwala. Sri Lanka

\begin{abstract}
As per Ayurvedic clinical practices, an individual is overwhelmed on one of human constituent type (Prakriti) specifically vata, pita or kapha. The determination of Prakriti offers remarkable bits of knowledge into comprehension and evaluating one's wellbeing. It isn't only an analytic tool yet additionally a manual for activity for good wellbeing. It surveys the, predominance of Prakriti and offers guidance for preventive and crude medical care. Potential infections that can be occurred due to prevailed humeral constituent type have been observed. COVID-19 is relied upon Vata Kapha constituent type. Acknowledgment of human constituent in Ayurveda, is as of now dependent on a pathological assessment on emotional models dependent on antiquated hypotheses of Ayurvedic scholar Charaka, 1000 BC and Susruta, 600 BC as an obsessive evaluation in clinical physiology.
\end{abstract}

Keywords-Ayurveda, Clinical physiology COVID-19, Human constituent, Pathological assessment.

\section{INTRODUCTION}

Ayurvedic medication has a solid bearing on the idea of Prakriti, which implies nature (normal type) of the fabricate and constituent of the human body. As per Ayurveda the way to ideal wellbeing is diverse for individuals relying upon their Prakriti. For people the Prakriti is characterized as a mix of (Vatha, Pittha and Kapha). Vata contains the components of Air (wind) and Ether (Space). The characteristics portraying Vata mirror its components. Pitta is comprised of the components of Fire and Water. Pitta characteristics mirror those of its components. Kapha is a mix of the components Water and Earth. Kapha mirrors the characteristics of those components. A fair condition of the Prakriti makes a sound and adjusted individual (Physically and intellectually). Since we as a whole have various blends of the Prakriti (8, 9, and 10). The analysis of Prakritii offers remarkable bits of knowledge into comprehension and evaluating one's wellbeing. It isn't only a demonstrative tool yet additionally a manual for activity for good wellbeing. It evaluates the, strength of Prakriti and offers guidance for preventive and crude medical services. The antiquated study of Ayurveda is the most established known type of medical care on the planet. Significant part of recognizable proof of constituent type is for determination of sicknesses, on the grounds that every one of constituent type has a rundown of likely maladies, for example, a significant specialized topic for some, physiologists is obsessive evaluation (5). A reasonable condition of these variables prompts immaculate wellbeing, and an imbalanced condition of any of these prompts ailment.

The blended kinds will have blended highlights speaking to the three human constituents and as needs be the overall blended sorts might be resolved. Another significant part of the investigation of humeral constituents is the overall helplessness of people of various constituents to various sorts of illnesses. As announced by Dubey and Singh (5) vata constitution people are moderately more powerless to irresistible ailments, as aspiratory tuberculosis, rheumatic fever and uneasiness problems like peptic ulcer and so forth. Also the pitta people generally experience the ill effects of hypertension, ischaemic coronary illness and rheumatord joint inflammation while Kapha people are bound to experience the ill effects of corpulence and unified tipid disoders, osteoarthhritis and so forth. Consequently the humeral constituent of a person speaks to a clear record of the hereditary cosmetics of the body and the psyche (2, 3, 4, and 5). In like manner it gives off an impression of being worried about the whole action of the living creature thus assumes an extraordinary part in all aspects of wellbeing and infection.

Medication is known to be the blend of science and craftsmanship. It is more genuine in the field of clinical finding (5). Most importantly thing the doctor needs to do is to win the certainty of his patient. Except if and until he prevails with regards to doing so a patient may not uncover a large number of his sicknesses and individual issues, 
which might be straightforwardly related with the malady cycle. This may have more pertinence if there should be an occurrence of psychosomatic issues and mental sicknesses. Caraka has underscored that if a doctor by prudence of his insight can't enter in the brain of his patients, he can't treat him effectively. Over the span of clinical assessment by plummet way, reasonable discussion and proper pathological assessment, one can win the certainty, which is more a workmanship than science

\section{DIAGNOSIS OF COVID-19}

Diagnosis of COVID-19 through Ayurveda is depict as given beneath (1):

Dosa - type of constituent: Aggregation of Kapha

Dooshya- Fever

Agni- Low digestion strength

Ama- Altered digestion and metabolism are obvious

Sroto-Respiratory tract

Sroto dusti prakara- Excessive flow

Symtoms exhibited area- Upper part of the body where Kapha is naturally dominant.

For the conditions influencing pranavasa srotas one needs to embrace Shwasa Chikitsa-the treatment suggested for windedness and related problems. Principle accentuation ought to be given on Vata Kapha constituent type with an accentuation on Pitta constituent. Acknowledgment of human constituent in Ayurveda, is at present dependent on a standard survey on emotional measures dependent on antiquated speculations of Ayurvedic scholar Charaka, 1000 BC and Susruta, 600 BC as a mental appraisal in clinical brain science. Inquiries in concerned are a lot of easy to understand and dependent on clinical speculations of Ayurveda, which is utilized for discovering constituent sort, has tests, for example, rehashing questions and arrangement of constituent type and its potential sicknesses $(6,7)$.

\section{ACKNOWLEDGEMENTS}

I must acknowledge Prof. Asoka S. Karunananda, Dr. Uditha Ratnayake, Dr. Udaya Samaratunga Dr. Thishantha Nanayakkara, Dr. Parakrama Welligamage, Royal Asiatic Society of Sri Lanka, and Sri Lanka Association for advancement of Science, SAARC Cultural Centre and Institute of Physics Sri Lanka for encouraging me to engage for a research culture.

\section{REFERENCES}

[1] Bekal S, Hebbar VJ, CoronaVirus: Ayurvedic Analysis, Possible prevention, Treatment Principles, Remedies [Internet], India, https://www.easyayurveda.com, 2020 [cited 2020 April 22] Available from https://www.easyayurveda.com/2020/03/16/coronavirusayurveda-prevention-treatment

[2] Prasher B, Negi S, Aggarwal S, Mandal AK, Sethi TP, Deshmukh SR, et al.(2008), Whole Genome expression and biochemical correlates of extreme constitutional types defined in Ayurveda. J Transl Med.pp.6-48.

[3] Bhushan P, Kalpana J, Arvind C. (2005), Classification of human population based on HLA gene polymorphism and the concept of Prakriti in Ayurveda. J Altern Complement Med.; 11:pp.349-53.

[4] Ghodke Y, Joshi K, Patwardhan B. (2009), Traditional Medicine to Modern Pharmacogenomics: ayurveda Prakriti Type and CYP2C19 Gene Polymorphism Associated with the Metabolic Variability. Evid Based Complement Alternat Med.

[5] G.P.Dubey (1978), The Physiological concepts in Indian medicine, Science and Philosophy of Indian medicine, Shree Beldyanath Ayurved Bhawan Ltd, 1978.

[6] Tripathi S.N., (1978), Clinical Diagnosis, Science and Philosophy of Indian medicine

[7] Seals D. R. (2013). Translational physiology: from molecules to public health. The Journal of physiology, 591(14), 3457-3469. https://doi.org/10.1113/jphysiol.2013.253195

[8] Central Council for Research in Ayurveda and Siddha Management of Chikungunya through Ayurveda and Siddha. New Delhi (2009)

http://www.ccras.nic.in/sites/default/files/22092016_MANA GEMENT\%20OF\%20CHIKUNGUNYA\%20TH ROUGH\%20AYURVEDA\%20AND\%20SIDDHAA\%20TECHNICAL\%20REPORT.pdf

[9] Govindaraj, P., Nizamuddin, S., Sharath, A. et al. (2015), Genome-wide analysis correlates Ayurveda Prakriti. Sci Rep 5, 15786. https://doi.org/10.1038/srep15786

[10] Chaudhari, D., Dhotre, D., Agarwal, D. et al. (2019) Understanding the association between the human gut, oral and skin microbiome and the Ayurvedic concept of prakriti. J Biosci 44, 112). https://doi.org/10.1007/s12038-019-99396

[11] Mendis, D.S.Kalana, (2020), A Commonsense knowledge system based on human constituents for diagnosis of COVID-19, International Journal of Engineering Applied Sciences and Technology, Vol. 5, Issue 4, pp. 13-16 